\title{
Comparative Study of In Vitro Antibacterial Activity of Miswak Extracts and Different Toothpastes
}

\author{
Sarmad Ghazi Mohammed \\ Department of Food Science and Biotechnology, Faculty of Agriculture, University of Basrah, Basrah, Iraq
}

Received 2012-08-28, Revised 2012-09-02; Accepted 2013-03-19

\begin{abstract}
This study determines the antimicrobial efficacy of miswak (aqueous and alcoholic) extracts comparing with five different toothpastes, which are available in Iraqi market, against different kinds of bacteria. The antibacterial efficacy of aqueous and alcoholic extracts of Salvadora persica and different kinds of toothpastes was studied against different cariogenic and pathogenic bacteria including Streptococcus mutans, Lactobacillus acidophilus, Escherichia coli, Staphylococcus aureus and Pseudomonas aeruginosa by well diffusion method. Salvodora persica extracts and toothpastes exhibited the greatest antimicrobial activities towards Staphylococcus aureus, Streptococcus mutans, Lactobacillus acidophilus, E. coli and Pseudomonas aeruginosa respectively. Alcoholic extract was dominant on aqueous extract in inhibiting the tested microorganisms. Toothpastes A were dominant comparing with the other toothpastes in inhibiting the tested microorganisms. The impact of toothpastes was almost more than Salvodora persica extracts on tested microorganisms. According to the good efficacy of Salvodora persica extracts on the tested microorganisms, it has antibacterial effects and could be used as a therapeutic agent and therefore, it appears to be a potent antimicrobial agents that could be considered as a medicinal plant.
\end{abstract}

Keywords: Miswak, Salvadora Persica, Chewing Sticks, Toothpastes Streptococcus Mutans, Antimicrobial Activity

\section{INTRODUCTION}

Plants are more important in human's life and fulfill his every day's needs. They are used as cosmetic, food, flavors, ornamental and medicine (Syam et al., 2008). Medicinal plants have become part of complementary medicine worldwide, because of their potential health benefits (Gomez-Flores et al., 2006). The use of medicinal plant as the first medicines is a universal phenomenon (Seyydnejad et al., 2010).

Various plant extracts have been widely used in the past to cure infectious diseases and healing of wounds. Plants have great potential against infectious agents and can be used for therapeutic purposes (Upadhyay et al., 2010).
Miswak (Salvadora persica) is one of the most commonly used medicinal plants for oral hygiene among global Muslim community (Sher et al., 2010).

The name Miswak, also called miswaak, siwak, siwaki depending on the Arabic dialect and the country, is known in English as the natural toothbrush (Elvin-Lewis, 1980; Hattab, 1997; Al-Sadhan and Almas, 1999).

The Miswak (miswaak, siwak) is a natural toothbrush made from the twigs of the Salvadora persica tree (Arak). Miswak was used by the Babylonians some 7000 years ago; they were later used throughout the Greek and Roman empires and have been used by Jews, Egyptians and in the Islamic empires. It is believed that this 
precursor to the modern day toothbrush was used in Europe until about 300 years ago. Today, Miswak is being used in Africa, South America, Asia, the Middle East including Saudi Arabia and throughout the Islamic countries (Kirtikar and Basu, 1996; Bhandari, 1990).

Extracts from Salvadora persica showed antibacterial activity against Streptococcus mutans and plaque control (Al-Lafi and Ababneh, 1995; Khalessi et al., 2004; Al-Otaibi et al., 2004; Almas et al., 2005).

The use of this stick as an effective tool for oral hygiene has been recommended and encouraged by the World Health Organization (WHO, 1987).

Many of the world populations including India, Pakistan, several African countries, the Arab countries and most of the Muslim world still use miswak (Corbet et al., 2000).

Various components of Salvadora persica have been reported to have beneficial biological properties, including significant antibacterial and antifungal activity (Al-Bagieh et al., 1994; Al-Lafi and Ababneh, 1995; Almas et al., 1997). Furthermore, extracts from miswak are reported to be effective against some periodontal pathogens and other bacteria that are important during development of dental plaque (Rotimi and Mosadomi, 1987; Almas, 2001; Poureslami et al., 2007; Sofrata et al., 2007).

Chemically, Salvadora Persica through chemical studies showed that it is composed of trimethyl amine, salvadorine, chlorides, high amounts of fluoride and silica, sulphur, vitamin C, small amounts of tannins, saponins, flavonoids and sterols (Darout et al., 2000; Alali and Al-Lafi, 2003)
Although the wide use of miswak in many countries, in Iraq it has not received any attention. Therefore, the aim of this study is to compare the antimicrobial activity of miswak extracts with five toothpastes against different species of bacteria using well diffusion assay.

\section{MATERIALS AND METHODS}

\subsection{Plant Material}

Collection of plant materials: Salvadora persica chewing sticks were purchased from the local market of Mecca-Kingdom of Saudi Arabia.

\subsection{Toothpastes}

Five brands of toothpastes were purchased from local market of Basra city-Iraq. Their ingredients are shown in Table 1.

\subsection{Preparation of Salvadora Persica Extracts}

Preparation of alcoholic extract of miswak was carried out by taking $800 \mathrm{~g}$ of Salvadora Persica chewing sticks and cutting them with a sharp knife. The resulting pieces of Salvadora persica were ground to a powder with a commercially available food blender. 120 $\mathrm{mL}$ of $60 \%$ ethanol was added to $40 \mathrm{~g}$ of powder in a sterile well capped flask, left for 3 days at room temperature and then filtered using number 1 filter paper. The extract then evaporated in a rotary evaporator at $40^{\circ} \mathrm{C}$ until ethanol removing. The extract stored in sterile screw-capped vials in the refrigerator until needed (Al-Koubaisi, 2001; Darmani et al., 2003).

Table 1. Ingredients of various toothpastes tested for its antimicrobial activity

\begin{tabular}{ll}
\hline Toothpastes & Ingredients as listed on packages \\
\hline A & Aqua, Sorbitol, Hydrated Silica, PEG-6, Sodium Lauryl Sulfate, Tetrapotassium Pyrophosphate, Disodium \\
& Pyrophosphate, Tetrasodium Pyrophosphate, Aroma, Cellulose Gum, Xanthan Gum, \\
& Sodium Fluoride, Carbomer, Sodium Saccharin, Triclosan, CI 77891, \\
& Glycerin, Limonene,CI 74160 Contains sodium fluoride (0.321\%) \\
& Precipitated calcium carbonate, sorbitol, silica, aluminum hydroxide, carrageenan, \\
B & CMC, fluoride, saccharine, sodium lauryl sulphate, sodium monofluorophosphate, flavor, water. \\
& Sorbitol, Hydrated Silica, PEG-8, Sodium Lauryl Sulfate, Cellulose Gum, Dicalcium phosphate \\
C & dehydrate, flavor, CI 77891, Sodium Fluoride, Sodium Saccharin, Propyl Paraben Sodium. \\
& Calcium Carbonate, Aqua, Sorbitol, Hydrate Silica, Sodium Lauryl Sulfate, Sodium \\
E & Monofluorophosphate, Aroma, Cellulose Gum, Potassium Citrate, Trisodium Phosphate, \\
& Sodium Saccharine, Cacium Glycerophosphate, Phenylcarbinol, Glycerin, Limonene, CI 12490 \\
& Sorbitol, Hydrated Silica, PEG-12, Sodium Lauryl Sulfate, Tetrasodium Pyrophosphate, \\
D & Cellulose Gum, Sodium Lauryl Sulfate, Flavor, Sodium Saccharine, \\
& Sodium Fluoride, limonene, CI 16035, CI 17200. \\
\hline
\end{tabular}


To prepare the aqueous extract, Salvadora persica chewing sticks were cut into small pieces and ground to powder form in a ball mill. The powder was weighed into $10 \mathrm{gm}$ portions and placed in a sterile screw capped bottle to which $100 \mathrm{~mL}$ of sterile deionized distilled water was added. The extract was allowed to soak for 48 $\mathrm{h}$ at $4^{\circ} \mathrm{C}$ before the mixture was centrifuged at $2000 \mathrm{rpm}$ for $10 \mathrm{~min}$ (Al-Lafi and Abadneh, 1995). The supernatant was passed through a $0.45 \mathrm{~mm}$ membrane filler. The extract stored in sterile screw-capped vials in the refrigerator until needed.

\subsection{Microorganisms}

Streptococcus mutans and Lactobacillus acidophilus were clinical isolates, Staphylococcus aureus Pseudomonas aeruginosa and Escherichia coli were obtained from the Department of Biology, College of Science, University of Basrah, Iraq.

\subsection{Antimicrobial Assay}

The antimicrobial activity of Salvadora persica extracts and toothpastes was determined according to Chrkraborty (1996). Nutreint agar poured in Petri dish. $0.1 \mathrm{~mL}$ (containing approximately $10^{5}$ bacteria) of Streptococcus mutans, Lactobacillus acidophilus, Staphylococcus aureus, Pseudomonas aeruginosa and Escherichia coli separately spreaded and a cork borer was used to make bore $(5 \times 5 \mathrm{~mm}$ in diameter $)$ on the surface. After surface solidification, $0.1 \mathrm{~mL}$ of Salvadora persica extracts and toothpastes was added to each bore. Plates were incubated in anaerobic jar at $37^{\circ} \mathrm{C}$ for 18-24 h. The antimicrobial activity of Salvadora persica extracts and toothpastes against Streptococcus mutans, Lactobacillus acidophilus, Staphylococcus aureus, Pseudomonas aeruginosa and Escherichia coli was determined by measuring the inhibition zones around each bore.

\subsection{Phytochemical Analysis}

Salvadora persica extracts were subjected to preliminary phytochemical analysis to find the presence of the following constituents: flavonoids, sterols, saponins, tannins, basic alkaloids, Reducing components (Edeoga et al., 2005; Egwaikhide and Gimba, 2007).

\section{RESULTS}

Antibacterial activity test showed that alcoholic extract of miswak had growth inhibitory effects on several tested microorganisms more than aqueous extract. Inhibition zone was wide against Staphylococcus aureus followed by Streptococcus mutans, Lactobacillus acidophilus, E. coli and Pseudomonas aeruginosa respectively for both extracts as shown in Table 2. For aqueous extract the inhibition zone ranged between 0 to $4.70 \mathrm{~cm}$, while alcoholic extract zone of inhibition ranged between 3.49 to $6.06 \mathrm{~cm}$.

For toothpastes antibacterial activity, toothpaste A had maximum zones of inhibition against the tested microorganisms compared to all other toothpaste formulations followed by D, C, E and B toothpaste formulations respectively as shown in Table 3 . Inhibition zone was wide against Staphylococcus aureus followed by Streptococcus mutans, E. coli and Lactobacillus acidophilus for most toothpastes. Toothpastes A and E had inhibition zone against Pseudomonas aeruginosa while toothpastes B, C and D had no inhibition zone against Pseudomonas aeruginosa.

Among all the investigated toothpastes, toothpaste a emerged as the most effective, based on the mean diameter of the zone of microbial inhibition produced by the toothpastes in agar well diffusion method, against all the five microorganisms tested. Its inhibition zones ranged between 4.00 to $700 \mathrm{~cm}$.

Table 2. Mean zone of inhibition (cm) of Aqueous and alcoholic extracts of Miswak

\begin{tabular}{lll}
\hline Microorganisms & $\begin{array}{l}\text { Aqueous } \\
\text { extract }\end{array}$ & $\begin{array}{l}\text { Alcoholic } \\
\text { extract }\end{array}$ \\
\hline Streptococcus mutans & $4.45 \pm 0.22$ & $4.57 \pm 0.33$ \\
Lactobacillus acidophilus & $4.23 \pm 0.13$ & $4.31 \pm 0.20$ \\
E. coli & $3.11 \pm 0.55$ & $4.00 \pm 0.00$ \\
Staphylococcus aureus & $4.70 \pm 0.67$ & $6.06 \pm 0.46$ \\
Pseudomonas aeruginosa & 0 & $3.49 \pm 0.66$ \\
\hline
\end{tabular}

Table 3. Mean zone of inhibition (cm) of toothpastes

\begin{tabular}{llllll}
\hline Toothpastes & $\begin{array}{l}\text { Streptococcus } \\
\text { mutans }\end{array}$ & $\begin{array}{l}\text { Lactobacillus } \\
\text { acidophilus }\end{array}$ & E. coli & $\begin{array}{l}\text { Staphylococcus } \\
\text { aureus }\end{array}$ & $\begin{array}{l}\text { Pseudomonas } \\
\text { aeruginosa }\end{array}$ \\
\hline A & $5.50 \pm 0.50$ & $5.00 \pm 0.60$ & $4.00 \pm 0.56$ & $7.00 \pm 0.00$ & $5.60 \pm 0.50$ \\
B & $3.00 \pm 0.00$ & $2.00 \pm 0.25$ & 0 & $4.80 \pm 0.22$ & 0 \\
C & $5.00 \pm 0.34$ & $5.00 \pm 0.00$ & $4.00 \pm 0.20$ & $5.25 \pm 0.30$ & 0 \\
D & $5.20 \pm 0.10$ & $4.50 \pm 0.30$ & $4.30 \pm 0.44$ & $5.40 \pm 0.00$ & 0 \\
E & $4.50 \pm 0.35$ & $3.00 \pm 0.00$ & 0 & $5.00 \pm 0.00$ & $2.50 \pm 0.00$ \\
\hline
\end{tabular}


Table 4. Phytochemical constituents of salvadora persica

\begin{tabular}{lll}
\hline Phytochemicals & Aqueous extract & Alcoholic extract \\
\hline Flavonoids & - & + \\
Sterols & - & ++ \\
Saponins & + & ++ \\
Tannins & + & ++ \\
Basic Alkaloids & - & + \\
Reducing components & + & + \\
\hline ++ Moderate presence, + = Slight presence, - = Absence
\end{tabular}

Phytochemical screening results of Salvodora persica extracts are shown in Table 4. For aqueous extract, results revealed absence of flavonoids, sterols and basic alkaloids, Slight presence of saponins, tannins and reducing components.

For alcoholic extract, results revealed slight presence of flavonoids basic alkaloids and reducing components. Moderate presence of sterols, saponins and tannins.

\section{DISCUSSION}

Chewing sticks selection in many countries based on many factors. The use of miswak is most common in the Middle East region, it is cheap, readily available in urban and rural areas of the countries. Its taste is agreeable and not unpleasant and reported to have anti-plaque and many other pharmacological properties (Lewis, 1980).

In the present study a variety of gram positive and gram negative bacteria were used in screening antimicrobial activity of aqueous and alcoholic extracts of Salvodora persica and different kinds of toothpastes.

The results of the current study clearly demonstrated that aqueous and alcoholic extracts of Salvodora persica as well as toothpastes could inhibit the growth of several cariogenic and pathogenic bacteria, however, the effectiveness varied against the different tested microorganisms.

Study results in agreement with (Almas et al., 2005; Darmani et al., 2006) who examined the effects of miswak extracts on the growth of the various cariogenic microorganisms including Streptococcus mutans. The result showed inhibition in growth of Streptococcus mutans. AL-Bayati and Sulaiman (2008) investigated the aqueous and methanol extracts of Salvadora persica for its antimicrobial activities against seven isolated oral pathogens. The aqueous extract inhibited all isolated microorganisms. Sofrata et al. (2008) reported antibacterial effect of Salvadora persica against oral microorganisms such as Streptococcus mutans, Lactobacillus acidophilus.
Al-Bayaty et al. (2010); Shingare and Chaugule (2011) and Masoumeh et al. (2012) had also found the miswak extract as an effective antimicrobial agent which is comparable to study results.

Salvodora persica extracts and toothpastes exhibited the greatest antimicrobial activities (as determined by the diameters of the inhibition zones) towards Staphylococcus aureus, Streptococcus mutans, Lactobacillus acidophilus, E. coli and Pseudomonas aeruginosa respectively, this result in agree with Al-Lafi and Ababneh (1995) who tested the antibacterial activity of Salvadora persica against some oral aerobic and anaerobic bacteria and reported that the extract of these sticks had a drastic effect on the growth of Staphylococcus aureus and a variable effect on other bacterial species.

Alcoholic extract was dominant on aqueous extract in inhibiting the tested microorganisms maybe because of its phytochemical constituents comparing with aqueous extract (Table 4). This result in agree with (Moustafa et al., 1987; Al-Bagieh and Almas, 1997) who found that ethanol extract of miswak has been shown to have a stronger microbial inhibitory effect on different microorganisms than the aqueous extract and in disagree with Al-Bayati and Sulaiman (2008) who found that aqueous extract of Salvadora persica was more effective than alcoholic extract in inhibiting tested bacteria. While toothpastes A was dominant comparing with the other toothpastes in inhibiting of tested microorganisms maybe because it has different components which may inhibited or reduced microorganisms growth.

Phytochemical constituents such as alkaloids, flavonoids, tannins, phenols, saponins and several other aromatic compounds are secondary metabolites of plants that serve a defense mechanism against prediction by many microorganisms, insects and other herbivores (Bonjar et al., 2004).

The phytochemical constituents of the selected plants investigated are summarized in Table 4 . Analysis of Salvodora persica extracts revealed the presence of flavonoids, sterols, saponins, tannins, basic alkaloids and reducing components in alcoholic extract and saponins, tannins and reducing components in aqueous extract which could be responsible for the observed antimicrobial property of alcoholic extract in compare with aqueous extract. This result in agree with (Wolinsky and Sote, 1984; Ohtani et al., 1992; Darout et al., 2000; AbdELRahman et al., 2003) who attributed the antimicrobial property of Salvodora persica extracts to its different phytochemical constituents.

These bioactive compounds are known to act by different mechanism and exert antimicrobial action. 
Flavonoids are hydroxylated phenolic substance known to be synthesized by plants in response to microbial infection and it should not be surprising that they have been found in vitro to be effective antimicrobial substances against a wide array of microorganisms. Their activity is probably due to their ability to complex with extracellular and soluble proteins and to complex with bacterial cell walls (Cowan, 1999). Sterols have been reported to have antibacterial properties, the correlation between membrane lipids and sensitivity for steroidal compound indicates the mechanism in which steroids specifically associate with membrane lipid and exerts its action by causing leakages from liposomes (Epand et al., 2007). Saponin antimicrobial property is due to its ability to cause leakage of proteins and certain enzymes from the cell (Zablotowicz et al., 1996).

Tannins bind to proline rich proteins and interfere with the protein synthesis (Shimada, 2006).

In this study, Staphylococcus aureus was found to be sensitive to alcoholic and aqueous extracts. The highest sensitivity of Staphylococcus aureus may be due to its cell wall structure and outer membrane (Zaika, 1988).

Study results suggest that gram-positive bacteria are generally more sensitive to the Salvodora persica extracts than gram-negative maybe because of the structure of membrane that the gram-positive bacteria are simpler than gram-negative ones. This was consistent with the previous studies on other spices and herbs (Ceylan and Fung, 2004).

Pseudomonas aeruginosa was resistant to aqueous extract and toothpastes B, C and D while E. coli was resistant to toothpastes $\mathrm{B}$ and $\mathrm{E}$. That probably could be due to cell membrane permeability or due to other genetic factors and this result is supported by (Nazif, 2002; Motamedi et al., 2009).

Finally, the impact of toothpastes was almost more than Salvodora persica extracts on tested microorganisms maybe because toothpastes have different components with sufficient concentration to be more effective comparing with Salvodora persica extracts.

\section{CONCLUSION}

The findings suggest that miswak extracts as well as toothpastes have an inhibitory effect on cariogenic and pathogenic bacteria. Toothpastes were almost more effective in inhibiting cariogenic and pathogenic bacteria compared to Salvodora persica extracts. Among toothpastes formulations, toothpaste a was found to be more effective than other toothpastes against the tested microorganisms. Miswak can be a good alternative to the toothpastes since it is inexpensive and readily available. It is available in most rural areas of the poor countries. It does not need expertise or any extra resources to manufacture it. Thus it appears to be a potent antimicrobial agent that could be considered as a medicinal plant.

\section{REFERENCES}

AbdELRahman, H.F., N. Skaug, A.M. Whyatt and G.W. Francis, 2003. Volatile compounds in crude Salvadora persica extracts. Pharmaceut. Biol., 41: 399-404. DOI: 10.1076/phbi.41.6.399.17826

Alali, F. and T. Al-Lafi, 2003. GC-MS analysis and bioactivity testing of the volatile oil from the leaves of the toothbrush tree Salvadora persica L. Nat. Prod. Res., 17: 189-194. PMID: 12737403

Al-Bagieh, N.H. and K. Almas, 1997. In vitro antibacterial effects of aqueous and alcohol extracts of miswak (chewing sticks). Cairo Dent J., 13: 221-224.

Al-Bagieh, N.H., A. Idowu and N.O. Salako, 1994. Effect of aqueous extract of miswak on the in vitro growth of Candida albicans. Microbios, 80: 107-13. PMID: 7898373

AL-Bayati, F.A. and K.D. Sulaiman, 2008. In vitro antimicrobial activity of salvadora persica L. extracts against some isolated oral pathogens in Iraq. Turk. J. Biol., 32: 57-62.

Al-Bayaty, F.H., A.H. AI-Koubaisi, N.A.W. Ali and M.A. Abdulla, 2010. Effect of mouth wash extracted from Salvadora persica (Miswak) on dental plaque formation: A clinical trail. J. Med. Plants Res., 4: 1446-54. DOI: $10.5897 / J M P R 10.198$

Al-Koubaisi, A.H., 2001. The Effect of Alcoholic Extraction of SalvadoraPersica (Miswak) on Dental Plaque Formation a 5-day Clinical Trail. M. Sc, Thesis, University of Baghdad, Iraq, pp: 1-50.

Al-Lafi, T. and H. Ababneh, 1995. The effect of the extract of the miswak (chewing sticks) used in Jordan and the Middle East on oral bacteria. Int. Dent. J., 45: 218-222. PMID: 7558361

Almas, K., 2001. The antimicrobial effects of seven different types of Asian chewing sticks. Odontostomatol. Trop., 24: 17-20. PMID: 11887585

Almas, K., N. Skaug and I. Ahmad, 2005. An in vitro antimicrobial comparison of miswak extract with commercially available non-alcohol mouthrinses. Int. J. Dent. Hyg., 3: 18-24. PMID: 16451373 
Almas, K., N.H. Al-Bagieh and E.S. Akpata, 1997. In vitro antimicrobial effects of extracts of freshly cut and 1-month-old miswak (chewing stick). Biomed. Lett., 56: 145-149.

Al-Otaibi, M., M. Al-Harthy, A. Gustafsson, A. Johansson and R. Claesson et al., 2004. Subgingival plaque microbiota in Saudi Arabians after use of miswak chewing stick and toothbrush. J. Clin. Periodontol., 31: 1048-1053. PMID: 15560804

Al-Sadhan, R. and K. Almas, 1999. Miswak (Chewing Stick): A Cultural and scientific heritage. Saudi Dent. J., 11: 80-88.

Bhandari, M.M., 1990. Flora of the Indian Desert. 1st Edn., MPS Repros, Jodhpur, ISBN-10: 8185304130, pp: 435.

Bonjar, G.H.S., S. Aghighi and A.K. Nik, 2004. Antibacterial and antifungal survey in plants used in indigenous herbal-medicine of south east regions of Iran. J. Biol. Sci., 4: 405-412.

Ceylan, E. and D.Y.C. Fung, 2004. Antimicrobial activity of spices. J. Rap. Meth Auto Microbiol., 12: 1-55. DOI: 10.1111/j.1745-4581.2004.tb00046.x

Chrkraborty, P., 1996. A Textbook of Clinical Microbiology. 1st Edn. New Central Book Agency, pp: 381 .

Corbet, E.F., K.Y. Zee and E.C. Lo, 2000. Periodontal diseases in asia and oceania. Periodontology, 29: 122-52. PMID: 12102706

Cowan, M.M., 1999. Plant products as antimicrobial agents. Clin. Microbiol. Rev., 12: 564-582. PMID: 10515903

Darmani, H., A.S. Al-Hiysat, A.M. Elbetieha and A. Alkafahi, 2003. The effect of an extract of Salvadora persica (Meswak, chewing stick) on fertility of male and female mice. Phytomedicine, 10: 62-65. DOI: 10.1078/094471103321648683

Darmani, H., T. Nusayr and A.S. Al-Hiyasat, 2006. Effects of extracts of miswak and derum on proliferation of Balb/C $3 \mathrm{~T} 3$ fibroblasts and viability of cariogenic bacteria. Int. J. Dent. Hyg., 4: 62-6. PMID: 16637906

Darout, I.A. A.A. Christy, N. Skaug and P.K. Egeberg, 2000. Identification and quantification of some potentially antimicrobial anionic components in miswak extract. Ind. J. Pharmacol., 32: 11-14.

Edeoga, H.O., D.E. Okwu and B.O. Mbaebie, 2005. Phytochemical constituents of some Nigerian medicinal plants. Afr. J. Biotech., 4: 685-688.
Egwaikhide, P.A. and C.E. Gimba, 2007. Analysis of the phytochemical content and anti-microbial activity of plectranthus glandulosis whole plant. Middle-East J. Sci. Res., 2: 135-138.

Elvin-Lewis, M., 1980. Plants used for teeth cleaning through the world. Am. J. Preventive Med., 6: 6170.

Epand, R.F., P.B. Savage and R.M. Epand, 2007. Bacterial lipid composition and the antimicrobial efficacy of cationic steroid compounds. Biochim. Biophys. Acta, 1768: 2500-2509. PMID: 17599802

Gomez-Flores, R., P. Tamez-Guerra, R. Tamez-Guerra, C. Rodriguez-Padilla and E. Monreal et al., 2006. In vitro antibacterial and antifungal activities of Nopalea cochenillifera pad extracts. Am. J. Inform. Dis., 2: 1-8. DOI: 10.3844/ajidsp.2006.1.8

Hattab, F.N., 1997. Meswak: The natural toothbrush. J. Clin. Dent., 8: 125-129. PMID: 9487831

Khalessi, A.M., A.R. Pack, W.M. Thomson and G.R. Tompkins, 2004. An in vivo study of the plaque control efficacy of Persica: A commercially available herbal mouthwash containing extracts of Salvadora persica. Int. Dent. J., 54: 279-283. PMID: 15503853

Kirtikar, K.R. and B.D. Basu, 1996. Indian Medicinal Plants. 2nd Edn., International Book Distributors, Dehradun, pp: 2791.

Lewis, M.E., 1980. Plants and dental health. J. Preventive Dent., 6: 75-80.

Masoumeh, K., A. Solmaz, K. Mahdi and V. Fariborz, 2012. Comparison of the antimicrobial effects of persica mouthwash and $0.2 \%$ chlorhexidine on aggregatibacter actinomycetemcomitans of healthy individuals and patients with chronic periodontitis. Res. J. Med. Sci., 6: 18-21.

Motamedi, H., A. Safary, S. Maleki and S.M. Seyyednejad, 2009. Ziziphus spina-christi, a native plant from Khuzestan, Iran, as a potential source for discovery new antimicrobial agents. Asian J. Plant Sci., 8: 187-190.

Moustafa, A.MM. El-All and A.K.M. El-Fadl, 1987. Reduced plaque formation by Miswak-based mouthwash. Egypt Dent. J., 33: 375-84. PMID: 3503729

Nazif, N.M., 2002. Phytoconstituents of Ziziphus spinachristi $\mathrm{L}$. fruits and their antimicrobial activity. Food Chem., 76: 77-81. DOI: 10.1016/S03088146(01)00243-6 
Ohtani, K., R. Kasai, K. Yamasaki O. Tanaka and M.S. Kamel et al., 1992. Lignan glycosides from stems of Salvadora persica. Phytochemistry, 31: 2469-2471. DOI: 10.1016/0031-9422(92)83301-E

Poureslami, H.R., A. Makarem and F. Mojab, 2007. Paraclinical effects of Miswak extract on dental plaque. Dent. Res. J., 4: 106-10.

Rotimi, V.O. and H.A. Mosadomi, 1987. The effect of crude extracts of nine African chewing sticks on oral anaerobes. J. Med. Microbiol., 23: 55-60. PMID: 3820271

Seyydnejad, S.M., M. Niknejad, I. Darabpoor and H. Motamedi, 2010. Antibacterial activity of hydroalcoholic extract of Callistemon citrinus and Albizia lebbeck. Am. J. Applied Sci., 7: 13-16. DOI: 10.3844/ajassp.2010.13.16

Sher, H., M.N. Al-Yemeni, S.M. Yahya and H.S. Arif, 2010. Ethnomedicinal and ethnoecological evaluation of Salvadora persica L.: A threatened medicinal plant in Arabian Peninsula. J. Med. Plants Res., 4: 1209-1215.

Shimada, T., 2006. Salivary proteins as a defense against dietary tannins. J. Chem. Ecol., 32: 1149-1163. PMID: 16770710

Shingare, P. and V. Chaugule, 2011. Comparative evaluation of antimicrobial activity of miswak, propolis, sodium hypochlorite and saline as root canal irrigants by microbial culturing and quantification in chronically exposed primary teeth. GERMS, 1: 12-21.
Sofrata, A., P. Lingström, M. Baljoon and A. Gustafsson, 2007. The effect of miswak extract on plaque $\mathrm{pH}$. An in vivo study. Caries Res., 41: 451-454. PMID: 17823507

Sofrata, A.H., R.L. Claesson, P.K. Lingstrom and A.K. Gustafsson, 2008. Strong antibacterial effect of miswak against oral microorganisms associated with periodontitis and caries. J. Periodontol., 79: 14741479. PMID: 18672998, DOI: 10.1902/jop.2008.070506

Syam, M., A.B. Abdul, S.I.A. Wahab, A.S. Al-Zubairi and M.M. Elhassan et al., 2008. Antibacterial and antioxidant activities of Typhonium Flagelliforme (Lodd.) blume tuber. Am. J. Biochem. Biotechnol., 4: 402-407. DOI: 10.3844/ajbbsp.2008.402.407

Upadhyay, R.K., S. Ahmed, R. Tripathi, L. Rohtagi and S.C. Jain, 2010. Screening of antimicrobial potential of extracts and pure compounds isolated from Capparis decidua. J. Med. Plants Res., 4: 439-445.

WHO, 1987. Preventive Methods and Programmes for Oral Diseases.

Wolinsky, L.E. and E.O. Sote, 1984. Isolation of natural plaque inhibiting substances from 'Nigerian chewing sticks'. Caries Res., 18: 216-225. PMID: 6584212

Zablotowicz, R.M., R.E. Hoagland and S.C. Wagner, 1996. Effect of saponins on the growth and activity of rhizosphere bacteria. Adv. Exp. Med. Biol., 405: 83-95. PMID: 8910697

Zaika, L.L., 1988. Spices and herbs: Their antimicrobial activity and its determination. J. Food Safety, 9: 97118. DOI: 10.1111/j.1745-4565.1988.tb00511.x 